\title{
The roles of all tiers of government and development partners in environmental conservation of natural resource: a case study in Nigeria
}

\begin{abstract}
Environmental damage usually comes back to development in one way or another and causes a development challenge. As the global demand for natural resources increases, human welfare and its implications relating to environmental degradation and exposure to environmental risks have caused many to lose their means of livelihood, triggering high level of poverty which remains a serious concern. However, globalization has played a central role in determining the future of the world. The role of globalization has proven to be essential to a nation's ability to yield the maximum potential from its available resources. The maximization of those resources generally leads to the improved economic development of the nation; wellbeing of man and the sustenance of his livelihood are closely associated with the natural resources base. Consequently, there is a global concern for natural resources protection and conservation so that man can continue to sustain his livelihood. Part of the overall development activities of man is industrial growth. As desirable as industries are, their growth is associated with deleterious consequences. This paper examined the threatened natural resources by mans various activities and call on all tiers of Government and Development partners on the need for natural resources conservation in Nigeria. This revealed that industrialisation and its concomitant urbanisation has brought to mans environment such negative factors like loss of biodiversity, enhanced greenhouse warming, desertification, drought, water and air pollution and accumulation of toxic wastes. It is believed that well conserved natural resources will bring economic, social, visual, and aesthetic benefits that guarantee sound and qualitative health of inhabitants. It concludes that conservation of African biodiversity has come to the fore due to its numerous cultural, scientific and economic values. Also, environmental protection regulations should be intensified to protect the environment from excesses exploitations and for sustainable development. This can be achieved principally through recognition, understanding, appreciating and/or integration of endogenous technologies with exogenous technologies whose synergies are capable of enhancing conservation of natural resource base.
\end{abstract}

Volume 4 Issue 3 - 2019

\author{
Raimi Morufu Olalekan,' Omidiji Adedoyin \\ $\mathrm{O},{ }^{2}$ Ebuete Abinotami Williams, ${ }^{2}$ Makanjuola \\ Bosede Christianah, ${ }^{3}$ Oshatunberu Modupe ${ }^{3}$ \\ 'Department of Community Medicine, Environmental Health \\ Unit, Faculty of Clinical Sciences, Niger Delta University, Nigeria \\ ${ }^{2}$ Department of Geography and Environmental Management, \\ Faculty of Social Sciences, Niger Delta University, Nigeria \\ ${ }^{3}$ Department of Environmental Health, College of Health \\ Sciences and Technology, Nigeria
}

\begin{abstract}
Correspondence: Raimi Morufu Olalekan, Department of Community Medicine, Environmental Health Unit, Faculty of Clinical Sciences, Niger Delta University, Wilberforce Island, Bayelsa State, Nigeria, Tel +2347038053786,

Email ola07038053786@gmail.com
\end{abstract}

Received: May 07, 2019 | Published: May 22, 2019

Keywords: tragedy of the commons, environmental conservation, natural resource, development partners, globalization, environmental risk, economic development

\section{Introduction}

Biological diversity and its conservation have become a major environmental problem in Africa, particularly in Nigeria. Before now, in many traditional African societies, use of natural resource base tended to cause little damage to biodiversity partly because of low population density. Besides, the local communities had belief systems and societal norms that encouraged or even enforced limits to exploitation of natural resources. In recent times, large scale loss of biodiversity has increased particularly within the rain forest belt, which harbours the bulk of Nigeria's heritage. ${ }^{1}$ Today, the genre of crisis we are facing in Africa in general and Nigeria in particular is natural resource degradation. Our lives and most of our livelihoods are based on biodiversity - the wealth of wild species. Like any inheritance, biodiversity can flourish if well managed, or it can be squandered and lost. Today massive loss of species and habitat will be slowed only when the human community understands that nature is not an inferior to be exploited or an enemy to be destroyed but an ally requiring respect and replenishment. In an era of accelerating globalisation, it is imperative that we are to have any hope of protecting and conserving our natural resources, we must understand the connections between the health of the world's economies and the health of resources on which our economies depend. Economists, financiers, businessmen, bankers, both government and development partners i.e. NGOs will have to recognise the hidden costs in the exploitation of the seas, land and the air for short term wealth. Nations are like people. Each must choose whether to live selfishly and complacently to act with courage and faith. All these paints an unflattering picture of the modern world, an energy glutton; a flagrant polluter of land, water and air; a greedy exploiter bent on economic gain and unconcerned with the environment. The view of history shows the shifting role of humans in the environment and increasing demands placed on air, water and natural resources; it also shows that as society gained control over the environment, the perceived link between human society and the natural world weakened. Human began to see themselves as apart from and superior to nature. ${ }^{2}$

The focus of all environmental problems is the rapidly increasing human population. This cannot be solved unless the total number of people on earth is proportional to what the environment could accommodate. Living environmental resources such as aquatic life's, forest and wildlife, are almost being used up completely. In addition, 
minerals, oil and ground water have been extracted in a large quantity and this poses greater risk for the future generations. ${ }^{3}$

\section{Literature review}

Today humanity is capable of destroying itself and every trace of life from the face of the earth. This can be brought instantaneously through a nuclear holocaust or gradually by degrading and destroying the environment. It is already known that many species have disappeared from the earth either due to over-exploitation or through destruction of the forest habitat. ${ }^{4}$ The forest reserves, water bodies and mineral resources constitute the natural wealth of a nation. The optimal exploitation of the available resources to enhance the course of modernisation is the means by which all nation states and people of all races measure and relates the value and contribution of their natural resources, to the quality of life. The exploitation of the natural resources to nurture the well being and development of any nation has both positive and negative externalities and thus, every nation takes measures to optimise the benefits from resource exploitation and minimise the many serious negative externalities associated with heavy resource exploitation, particularly the incidence of environmental damage, pollution and ecological degradation. ${ }^{5}$

The tools of human culture and civilisation destroy the ecological balance on which our very existence depends, creating the ironic situation where humanity search for a better life, implants the seeds for own destruction (committee on vital environmental resources) ${ }^{6}$ There is no doubt that human activities have impacted negatively on the Nigerian environment. Oil exploration and associated activities continue to devastate the ecology of the Niger Delta region. Human activities have intensified desertification in the Northern part of the country and have led to shrinkage of the surface area of Lake Chad. The Sahara Desert is moving southward at the rate of $1-5 \mathrm{~km}$ per year (estimate of the 1990s). BBC now gives the rate of $10 \mathrm{~km}$ yearly, claiming thousands of square kilometres of arable land. Nigeria rich biodiversity with over 5,303 plant species and about 484 plant species in 112 families are now threatened with extinction. Many of these are located in the Sahel. $43 \%$ of Nigeria's land mass in the north is under severe desert threat. African continent is losing 10million acres of forest every year to climate change. ${ }^{7,8}$ Globally, human activity not only causes climate change, it has also led to what scientists describe as the sixth extinction of life on earth. The sixth is artificially induced by human actions. ${ }^{7,8}$ Human activity is effecting changes in biodiversity which is in turn inducing the disappearance of plant and animal species at an alarming rate. If the trend continues the world could lose $20 \%$ of all existing species by 2020 . All these could have devastating consequences for the survival of human species. ${ }^{9}$

Biological diversity is threatened because people are out of balance with their environment, when benefits are being gained from exploiting natural habitat without paying the full cost of such exploitation. ${ }^{3}$ Nigerian deforestation rate is about $3.5 \%$ per year and the country forest presently occupy $923,767 \mathrm{~km}^{2}$ representing $10 \%$ of the nations forest land area. This is well below Food and Agricultural Organisation (FAO) recommended national minimum of $25 \%$. Deforestation leading to degradation is widespread resulting in the imbalance of the ecosystem. This is a serious problem in Nigeria, which currently has one of the highest rates of forest loss in the world. ${ }^{7,8}$

In our lifetime, as populations and expectation have doubled and redoubled, life has gone out of balance, forcing increasing billions of people to live in poverty. Today $80 \%$ of the natural resources (woodlands) that originally circled earth's surface in abundance have been cleared, fragmented or degraded. Most of the natural forest that remains occurs in just a few places. These forest blocks are valuable because they house indigenous people and culture, shelter bio-diversity, contribute to economic growth, protect water sources and provide recreation. ${ }^{10}$ The destruction of earth natural resources e.g. rainforest (10-20) hectares, or 25-30acres every single minute is alarming, especially when half of all prescription medicines comes from natural sources like plants and nearly half of all plant species are found in rainforests. ${ }^{11}$ Man has therefore lost the capacity to foresee and to forestall. He will end by destroying the earth. Unless human societies repent from their sins against nature and work for a return to harmonious relationship with the natural world. However, man in all efforts to have mastery over the nature has further dependent on nature. On account of such unthoughtful and ruthless exploitation the human society has vastly modified the ecosystems in different parts of the world and has brought undesirable changes in the natural habitats. Some natural stocks of plants and animals have disappeared. About 1000 species are currently threatened with extinction or are dangerously rare. ${ }^{11}$ The space human encroachment in nature has deprived the world civilisation of 130 mammal species and has endangered more than 250 species. Out of the total of approximately 0.3 million species of plants in the world, over 20,000 are in the category of either endangered or threatened with extinction. It is estimated that over 1000 animal species and 20,000 flowering plants are likely to be endangered globally. ${ }^{12}$ Now in almost every advanced country, overpopulation has been a vital concern along with the atmospheric pollution. Every effort is being made to save mankind from self-destruction. There are various problems which have arisen due to individual and agricultural development activities. Many of these problems are due to mismanagement of natural resources and their impacts are not localised but are universal in nature. ${ }^{1}$

The relevance of biodiversity to sustainable development is that wild species and genetic variations within them make critical contributions to agriculture, medicine and industry. Perhaps even more important are the essential life processes that are carried out by nature including stabilisation of climate, protection of watersheds, protection of soil, protection of nurseries and breeding ground. ${ }^{13}$ Biodiversity loss is a serious environmental problem at the local and regional levels. These problems have global dimension which are linked with threats to sustainable development and poverty alleviation. ${ }^{14}$ The biodiversity of a nation is crucial to its socio-economic development. It provides the basis of support for life. It is a function of the country's large geographical extent and the diversity of its environment. ${ }^{1}$ The humid forests are outstanding examples of complex biodiversity communities. Loss of species is adversely impacting on the delivery of ecosystem services. The continued decline in plant species is particularly serious because the use of native plants not only protects a nation's natural heritage and provides wildlife habitat, but also can reduce fertiliser, pesticide and irrigation demands and the associated costs. This is because according to Smith and Smith, ${ }^{15}$ Smith ${ }^{16}$ native plants are suited to the local environment and climate.

Rational use of natural resources is the only means to maintain and improve human conditions. However, in the use of natural resources, one needs to appreciate the impact of one action on the resources and the society. Concern over the environmental aspects of natural resources use and management emanates from an unprecedented rate of population growth, rising income per capital demand. These have, in recent years, been magnified by scientific and technological advances which create new demands. In order to meet these new 
demands, Nigerians has to be compelled to put additional pressure on the natural resources. Such pressures often exceed the capacity of the system to bear. What has therefore been advocated worldwide is the concept of integrated resources management. This means that in altering one element in the system for the purpose of deriving advantages, one should understand the impact of that alteration upon the remaining component of the system. Also, one should carefully calculate what should be done to make the system as a whole, as productive as possible to prevent the benefits that the modification makes possible from collapsing because crucial natural links have been interfered or terminated. ${ }^{17}$

\section{Inventory of environmental/natural resources}

Environment has been conceived as a system where living organisms interact with the physical elements. This system is alternatively known as the ecosystem. In this view, man as part of the living organisms interacts with other organisms within the environmental set up. ${ }^{18}$ The entire environment can be classified under two broad headings as the natural and cultural environments. The former covers the atmosphere (gases such as Nitrogen, Oxygen and Carbondioxide), hydrosphere (water bodies such as lakes, rivers, oceans and seas as well as underground water), lithosphere (rocks and minerals) and biosphere (plants, animals and organisms) as reported by Olorunfemi and Jimoh. ${ }^{19}$ The later is the cultural environment, which is the man spatial unit. ${ }^{20}$ Within these environmental spheres, are a number of interactions that propelled the different types of human related activities? As a result, interactions easily translate into different environmental related problems, which impact some negative influences on man. ${ }^{21}$ For the attainment of sustainable development, which is the main focus of development policies of the developing countries, it is necessary to find means of addressing the issue of overuse of environmental resources as well as the consequences. It thus become pertinent, to assume that man is not aware of the consequences of his actions and as such needs to be informed irrespective of perception and culture. ${ }^{11}$

\section{What is conservation?}

Conservation, according to Allaby ${ }^{22}$ is the planning and management of resources in order to secure their wise use and continuity of supply and possibly enhance their quality, value and diversity. Modern conservation, therefore, is the management of the human use of the environment such that it may yield the greatest sustainable benefit to the present generation. ${ }^{23}$ The issue of conservation is dynamic and covers a wide range of concepts. From a panoramic perspective, the term conservation can mean the wise application of landscape techniques. ${ }^{24}$ Thus, a fundamental technique of conservation is that the use of any resource requires the consideration of its impacts on the environment. It therefore transcends protection and preservation to judicious use of resource to ensure sustainability and to avoid disastrous consequences that may attend the use of this resources. ${ }^{25}$

\section{Conservation and economic development}

Should our economy kill the earth? We do not inherit the earth from our ancestors; we borrow it from our children. The destruction of nature is a modern sin. Many of the most seriously threatened species and ecosystems of the world are in the developing countries, especially in the tropics. This situation concerns us all because these countries are the guardians of biological resources that may be vital to all of us. Unfortunately, where political and economic systems fail to provide people with land, jobs and food, disenfranchised citizens turn to legally protected lands, plants and animals for their needs.
Immediate human survivals always take precedence over long term environmental goals. Clearly the struggle to save species and unique ecosystems cannot be divorced from the broader struggle to achieve a new world order in which the basic needs of all are met. ${ }^{26}$

The tropics are suffering the greatest destruction and species loss in the world, especially in humid forests and coastal ecosystems. People in some of the affected countries are beginning to realise that the biological richness of their environment may be their most valuable resources and that its preservation is vital for sustainable development. Ecotourism can be more beneficial to many of these countries over the long term than the extractive industries such as logging and mining. ${ }^{26}$

In many cases, sustainable production of food, fiber, medicines, and water in rural areas depends on ecosystem services derived from adjacent conservation reserves. Tourism associated with wildlife watching and outdoor recreation can be a welcome source of income, wealth, livelihood and survival for underdeveloped countries. If local people share in the benefits of saving wildlife, they probably will cooperate, and the programs will be successful. To reformulate Thoreau's famous dictum, in broadly shared economic progress is preservation of the wild.

\section{Tragedy of the commons}

This concept is used to illustrate and account for situations in which the depletion of natural resources occurs because individual and collective interest do not coincide and no individual or institution has the power to ensure that they do. ${ }^{1}$ The concept focuses on the way public resources are misused by each of us because of our unwillingness to use a minimum share of a resource. Ayuba and Dami gave the example of fishermen who are likely to take as many game fish as possible out of a lake where there is no rule to stop them. This is because they feel that if they do not catch them, others will. The same principle applies to the misuse or over exploitation of any renewable and non-renewable resources. It is clear that a resource is exhaustible if the pattern of use makes its supply dwindle to zero. The misuse or what we call vandalisation of resources can be described in terms of the concept of Tragedy of the commons.

\section{Resource extraction problem}

The natural resource extraction related environmental problems include: oil and gas pollution problems associated with spills, oil well blow outs, ballast discharges, improper disposal of drilling mud, gas flaring; the non-reclamation of mining waste-lands and pits; uncontrolled logging and tree felling accentuated by lack of restocking, rapidly declining wildlife, exploitation of marginal lands, the destruction of watershed, bush burning a most destructive hunting method for wildlife delicacies (bush meat); overgrazing, uncontrolled fuel wood extraction, etc. In 1950, African livestock and human population were 272 million and 238 million respectively. By 1987, the figures rose to 543 million livestock and 604 million people. Productivity of the land easily becomes reduced by the physical stress of fuel wood extraction, bush burning and over-grazing. ${ }^{27}$

In the Sudan, wood accounts for 80 percent of the fuel for household and small-scale industries. In Niamey, the capital of Niger, $25 \%$ of workers family income is spent on fuel wood. Deterioration of grassland accelerates soil erosion, further reducing the carrying capacity of the soil and setting in motion of self-reinforcing cycle of ecological degradation and deepening human poverty. Under conditions of drought the dry lands become severely desertified. ${ }^{27}$ 
Nigeria has the third highest rate of deforestation in the world: $3.7 \%$ or 410,000 hectares of forests annually; with some areas in the South losing over 1,000 hectares/year. The country has lost almost $50 \%$ of its forest resources between 1990 and 2010 when its forest area shrank from $17 \mathrm{mln}$ hectares down to $9 \mathrm{mln}$ hectares. With continuation of current trends unaltered it is a matter of just a few decades when all Nigeria's forests might be gone. Unsustainable and constantly growing consumption of fuelwood by Nigerian households is one of the main causes of deforestation. More than half of the 9.6million hectares of rain forest belt in the south of Nigeria have been used to meet the demand for fuelwood in rural and urban areas. Fuelwood use has grown from $50 \mathrm{mln} \mathrm{m}^{3} /$ year in 1990 up to $70 \mathrm{mln}$ $\mathrm{m}^{3} /$ year and accounts for significantly higher share of forest product use than, for example, commercial logging; the latter makes only $11 \mathrm{mln}^{3} /$ year in 2010 and didn't register any major changes in the last decades. This increase is largely due to population growth, but also due to the absence of affordable alternatives, especially for the poorest consumers. On the contrary, due to rising prices for fossils fuels, a massive shift from "modern" fuels like kerosene and LPG back to fuel wood has been taking place ("reverse substitution with wood fuel", according to the FAO). Deforestation is the largest source of GHG emissions in Nigeria: it is responsible for $40 \%$ of national $\mathrm{CO}_{2}$ emissions. According to National Communication to UNFCCC, under baseline scenario emissions from deforestation will increase from $9.5 \mathrm{MtC} /$ year in 1990 up to $26.5 \mathrm{MtC} /$ year in 2030 (based on a conservative deforestation rate of only $2.6 \%$ ).

\section{The nature of natural resources and associated problems in Nigeria}

Scanty attention to resources conservation, hitherto, has created the abuses/problems of resources. Nigeria, like any other developing country, is experiencing rapid urbanisation (caused by rural-urban migration), which over two decades ago was put at 11 percent per annum while population growth rate is of 3 percent annually (Sada and Oguntoyinbo, 1981). This has brought about various environmental problems such as loss of biodiversity and enhanced green house warming, desertification, salinization of agricultural land, air and water pollutions, bush burning, rainstorms, erosion and accumulation of toxic wastes. ${ }^{28-30}$ The above problems are symptoms of a declined environmental integrity, and indicative that man is in danger of the breaching environmental system resilience. Environment and development are inseparable features of any country. ${ }^{31}$ Both are interrelated, interconnected, and interdependent to some degree. The need for conservation then emerges, since the later affects the former, and negatively. Man, owing to the privilege offered by industrial and technological revolution of our present world, has acquired unlimited powers to misuse the environment instead of conserving it for future benefits. The result of these is environmental crisis, which puts mans survival at stake. ${ }^{25}$

Fictitious needs like brewery products, cosmetics, unnecessary pharmaceuticals, luxury and fancy goods, pesticides, detergents etc are invading the market economy luring the consumers with false propaganda and glamour. The resources, which could have been utilized to meet the real needs of mankind, are being wasted. Energy consumption in producing the unwanted fancy goods and the environmental pollution released by these manufacturers are added abuses to the society.

The process designs of industrial manufacturing were concentrating on the cost-benefit analysis from the manufacturer's point of view only. Hence the possibility of recycling of wastes, use of renewable resources in preference to the non-renewable ones, complete utilization of the resources without throwing away the less useful components and other possible resources conservation measures were not exploded.

Priorities in the usages of precious resources were not fixed up. Thus, land is used to raise commercial or useless crops like tobacco, instead of cultivating more needful but less profitable crops. The monopoly of natural resources by private individuals, institutions and state governments prevent the optimum utilisation of the resources in national interests.

Inefficient planning and maintenance are also responsible for the wastage of resources. Oil spills, gas leaks, spoilages during storage, unauthorized usages of lesser utility and wasteful transports can be decreased with proper planning.

Intangible resources like intelligence, entrepreneurship, enthusiasm and knowledge are not mobilized to enhance productivity due to poor planning and inefficient leadership.

\section{Role of all tiers of government in natural resources conservation}

\section{Federal/National Government}

A federation may be defined as an association of states in which governmental powers are divided between the federal and state governments which are respectively coordinate (independent) and supreme in the performance of their functions for the people. ${ }^{32}$ The federal functions are called exclusive functions while that of states are referred to as residual functions. ${ }^{33}$ Some of the roles, which the federal government can play in form of policy instruments in ensuring, to a higher degree, environmental conservation in Nigeria are:

1) The Federal Government can encourage the general populace to desist from actions that could affect the environment in a negative form through the use of the media.

2) Direct controls, by giving regulations as in air pollution limiting the permissible levels of emissions as well as stipulating the ways such should be done effectively.

3) The Federal Government can use market processes in form of collecting taxes on damage done to the environment. The rates could be based on evaluation of social damage and what is designed to achieve present standards of environmental quality. In addition, subsidies could be paid to industries per unit of reduction of waste emissions as well as those paid by the government to industries to defray costs of damage control equipment. Others are issuance of limited quantities of pollution licenses, collection of refundable deposits against environmental damage and allocation of property rights to give individuals a proprietary interest in an improved environmental quality.

4) There is need for Federal Government to invest in damage prevention facilities (e.g municipal treatment plants), regenerative activities (e.g. forestation, slum clearance), dissemination of information (e.g. pollution control techniques, opportunities for profitable recycling), research, such as inducing research students, environmental specialists and research institutes to focus on environmental conservation and education, educating the general public and professional specialists (e.g. ecologists, urban planners) in environmental issues.

5) Administrative mechanism such as; Administrative units e.g. 
national, state and local agencies and financing agencies set up for environmental conservation at the national, state and local levels. This could be generated by those who caused the environmental damage, payment by those who benefit from environmental improvements as well as those derived from general revenues. Using enforcement mechanism in terms of regulatory organisation or police and making case with those individuals who violate environmental laws, with or without fines attached.

\section{State government}

To some degree, the state is expected to play roles similar to that of federal government depending on the level of resources at her disposal. In addition, the states responsibilities in environmental protection/sanitation agencies. Some of the policies especially, the legal enactment together with the national constitutions, take the bulk of the blame on the duplication of functions of agencies governing environmental issues. ${ }^{33}$

Effective Implementation of necessary measures, as outlined in the statement, will be facilitated by a partnership role of the three tiers of Governments. Many environmental problems assume national significance. Hence, the policies and programmes of the federal and state level should be drawn up, keeping in view overall national policy considerations. A monitoring mechanism involving federal and state government representatives will be set up for interaction as required for implementation to the policy initiatives. Others include:

i. Strengthening of state institutions and legislations.

ii. Enhancing state national resources accounting.

iii. Training and Orientation Program on state resources conservation.

iv. Promoting environmental awareness and consciousness among state citizen.

v. Promoting appropriate environmentally friendly technologies in the state.

vi. Partnership with Woman in environmental conservation and rehabilitation.

\section{Local government}

In Nigeria, Local Government, form the third tier of Government and it is the closest to the local people. The various functions of local Government are easily felt by the local population before that of the state let alone the Federal Governments. The Local Government has been saddled with lots of responsibilities in Nigeria by the 1976 Local Government Reform. ${ }^{1}$ One of the primary responsibilities of Local Government is the planning and control of development in its area of jurisdiction, (Federal Republic of Nigeria, 1976:3). ${ }^{34}$ Thus, they have the opportunity of greater potential for bottom-up people oriented participatory environmental conservation affairs. The following are some of the roles, which Local Government can play in environmental conservation matters:

a. Entering into partnership with other public agencies and civil society organisations on issues dealing with environmental problems

b. Creating environmental education and awareness programmes within its sphere of jurisdiction, to the local community using local government information gadgets and traditional rulers to pass such information.

c. Organisation of environmental related conferences for all her employees on the need for conservation of the environment/ natural resources.

d. Incorporation of environmental conservation concept in all dayto-day functions of local government departments.

e. Initiation of Local Government environmental conservation committee in each of the Local Governments all over the nation, made up of all the departmental heads and units, supervisory councillors, representatives of the private sector and representative from each of the wards, with the Local Government secretary as the committee secretary

f. Stirring the entire social structure including the private sectors within the Local Government to corporately address environmental problems plaguing them.

g. Adopting polluter charges as a matter of policy to ensure water, air and land quality

h. Liaising regularly with relevant State and Federal Government agencies as well as NGOs on development activities that portend adverse effect within the Local Government area.

i. Formulation of relevant byelaws backed up with police power for the conservation of both physical and cultural environment.

j. Allocating enough capital for the pursuance of environmental conservation projects or activities, among others.

k. Playing the role of an advocate on environmental conservation matters.

\section{Development partners (The Non-Governmental Organisation)}

NGOs hold a great potential to be efficient and effective alternatives to government agencies in the delivery of programmes and projects. They are also displaying a far greater level of professional competence in questioning and projecting alternatives to official development programmes. The NGOs and private sectors have done little to support environmental conservation in Nigeria. The NGOs that support environmental conservation in Nigeria are very few. However, they can play some significant roles in ensuring healthy environment by preaching environmental conservation.

i. The NGOs could sponsor various environmental education and awareness programmes on the media to educate the general people on the need to preserve environmental purity, which consequently enhance sound health.

ii. At the primary and secondary level, they (NGOs) can distribute environmental related materials to the students, which will sensitise them about the delicate state of the environment.

iii. Scholarships could be awarded to best students at the higher institutional levels to encourage students studying courses that are environmentally related.

iv. At Local level, the NGOs could organise lectures on environmental conservations and distribute seedlings to farmers with the aim of encouraging reforestation and afforestation.

v. Organising and funding local extension agencies that will monitor the activities of the local people on the environment and serving as advisory body to the local people on issues that have to do with the environment. 
vi. NGOs can also give training assistance to any would be environmental prospective. Emphasis on human resources development is crucial to the success of environmental conservation projects, principles and methods.

vii. Managerial capacity of the NGOs should be strengthened. Training programmes for NGOs on regional basis should be organised. An advisory cell for rural NGOs should be made available to all district headquarters.

viii. Non-Governmental organisations, citizen groups and village level institutions like foresters should be empowered with locus standi and support for mobilisation of public opinion and participation in development activities.

ix. Environmental Information centres should be set up at the district level to generate knowledge regarding traditional and endogenous system management practices. NGOs at the district level should be involved in the management and dissemination of the environmental information.

x. Implementation of the conservation strategy would be impossible without active participation of the people. Non-Governmental organisations (NGOs) can play an important role in mobilising the people at grassroots. This will need a network among NGOs and interface between the people and the Government to work on community involvement, providing information on environmental surveillance and monitoring, transmitting development in science and appropriate technology to the people at large. ${ }^{35}$

xi. NGOs should also invest in research on natural resources conservation and environment.

xii. None of these means can yield the expected result but a combination of them, and it must be stressed that the NGOs alone cannot guarantee environmental conservation they have to combine efforts with the federal, state and local governments. Additionally, principle 2 of the Stockholm declearation of 1972 proclaim that: The natural resources of the earth including the air, water, land, flora and fauna and especially representative samples of natural ecosystems must be safeguarded for the benefit of present and future generations through careful planning or management, as appropriate.

\section{Constraints and Prospects on Natural Resources Conservation in Nigeria}

There are certain problems that are likely to face efforts geared towards natural resources conservation by NGOs and the various tiers of governments. These are enumerated below as:

a) Political Instability

b) Frivolity on the part of those concerned (agencies) on natural resources conservation

c) Non-chalant attitudes and dishonesty by members of the public

d) Non-involvement of popular section e.g. the communities

e) Poor budgetary allocation

f) Partisan politics and politicisation of natural resources conservation issues e.g. land use regulation

g) Inadequate or lack of publicity on natural resources problems h) Non-availability of planning tools for natural resource conservation such as base maps,

i) Natural resources inventory and action plans

j) Lack of unity among stakeholders on decisions at conserving the natural resource

k) Poor local technical and coordination capacity

1) Lack of trust in the way capital assigned to natural resources conservation is being handled

m) Lack of monitoring of natural resources conservation project, among others.

However, natural resources conservation is one of the areas where a great demand exists for practical solutions, ${ }^{36}$ to environmental problems that besiege man today. It attracts many researchers who are personally committed to natural resources issues and interested in improving the situation. Not only that a well-conserved natural resource brings economic, social, visual and aesthetic benefits but also guarantees sound qualitative health of the inhabitants.

With these few problems and challenges at hand, one can suggest strategies with which we can use in order to make clever use of the natural resources, some of them are as follows: Developing monitoring and evaluation framework in environmental conservation of natural resource, Re-orientation, Mass literacy campaign, Mass enlightenment campaign, Re-afforestation, Popular participation, Control of forest exploitation, Formation of conservation clubs, Abolition of some habits, Forest tracing, Review of land use system, Cleaning up the pollution, Natural resources monitoring and surveillances, Enforcement of existing legislation, Poverty alleviation schemes, Early warning system, Adaptive research and technology, Environmental/natural resources education, Political will, Improving equality of the environment through waste management etc (Figure $1-3) \cdot{ }^{37}$

\section{Land clearing for Crop Production}
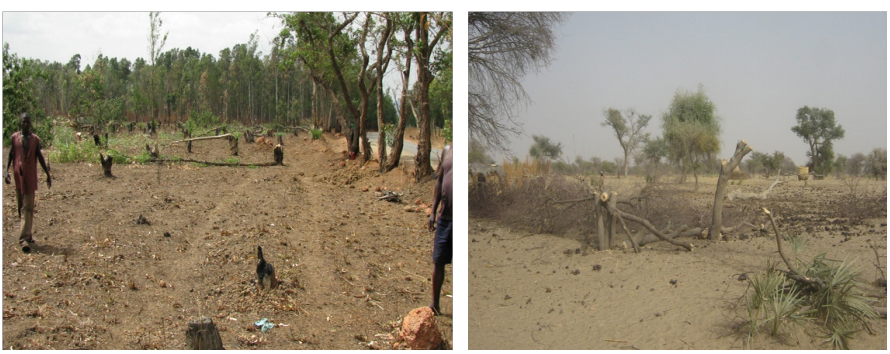

Figure I Shows land clearing for crop production.

\section{Land degradation}

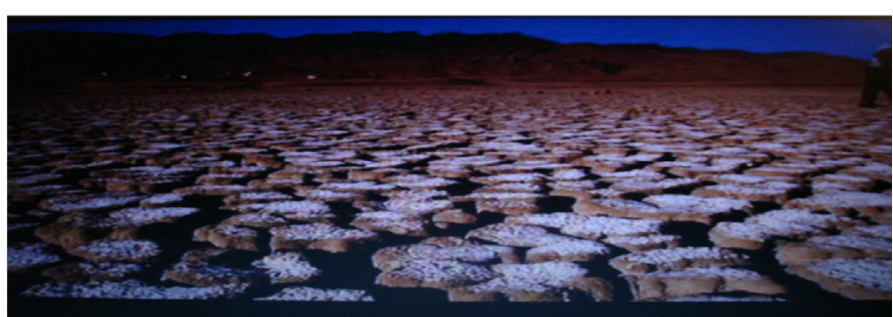

Figure 2 Shows land degradation. 


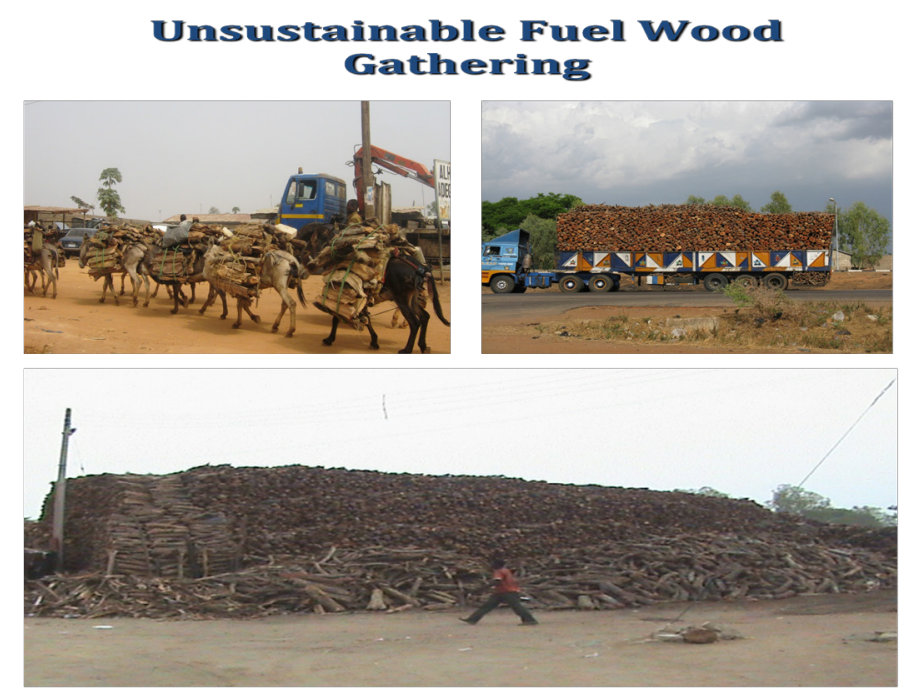

Figure 3 Shows unsustainable fuel wood gathering.

Source: All photographs are adapted from author's field trip report, $201 \mathrm{I}$.

\section{Conclusion}

The task before us would be daunting if it were not for the many positive factors that are emerging: People movement to conserve their own environment as the case of Chikpo movement in India, greater public and media concern for environmental issues and spread of environmental awareness among the children and youth. It is up to us, as state and citizens, to undertake development process in keeping with our heritage and the traditional conservation ethos and in harmony with the environmental imperatives of this land. Moreover, the problems call for a quick attention of all, especially the Development partners (NGOs) and governments at various levels, in the conservation, of all environmental resources for the benefit of all. It is obvious that the environment, in which man finds himself, is very complex and there are interrelationships among living things. However, various human activities have began to change the environment at larger scale in ways harmful to man and living things. Urgent solutions to environmental problems must therefore be sought particularly in urban settings where qualitative environment is more or less becoming a mirage. As a matter of fact, the Non-governmental organization (NGOs), Government organisations and the entire citizenry must rise to these environmental challenges quickly. Focus must therefore be centred on towns and cities that are the liveable environment where harmony must exist between all human activities so as to ensure a qualitative environment for all.

Interestingly, Africa today is a subset of a global village endowed with abundant natural resources, which surprisingly are becoming over exploited. This trend breeds natural resources degradation. The factor of rapid urbanization coupled with accelerated industrialisation has brought on natural resources such as problems as loss of biodiversity and rapid ozone depletion, desertification, land, water and air pollution as well as bush burning, erosion and accumulated wastes which could be simply summarised under the name natural resource degradation. All these necessitated the need for conservation of our dear natural resources. Thus far, the NGOs as well as all the various tiers of governments have abundance of untapped resources (human, materials and financial), which could be channelled towards natural resource conservation in Nigeria. Although, a number of constraints have been identified in the course of the study which could hamper all efforts at ensuring natural resources conservation in Nigeria, however these could be put behind us if all hands are on deck at rallying round sound, clean and sustainable natural resources.

\section{Acknowledgments}

None.

\section{Conflicts of interest}

The authors declared there is no conflict of interest.

\section{References}

1. Ayuba HK, Dami A. An introduction to environmental science text. Maiduguri, Apani Business and Research Consult. 2011.

2. Daniel DC. Environmental science: a framework for decision making. Addison-Wesley Publishing Company; 1989.

3. Khitoliya RK. Environmental pollution management and control for sustainable development. New Delhi: S Chand and Company Ltd; 2004.

4. Dhameja SD. Society and environment; as per AMIE section a new syllabus. SK Kataria and Son; 2007.

5. Augustine AI. The petroleum question: towards harmony in development. $5^{\text {th }}$ Inaugural Lecture, Wilberforce Island: Niger Delta University; 2014.

6. Daily Trust Lagos. 2011. 53 p.

7. Raimi MO. The Effect of Vehicular Emission on Human Health, A case study of Yenagoa Motor Parks. Presented to the Department of Geography and Environmental Management, Wilberforce Island, Bayelsa State: Niger Delta University; 2008.

8. Raimi MO, Tonye V. Odubo, et al. Environmental health and climate change in Nigeria. Valencia, Spain: World Congress on Global Warming; 2018 .

9. The Guardian Lagos. 2008. 53 p.

10. Global Christian update. 2011;1(2):13.

11. Awake. Is belief in a creator reasonable! 2011.

12. The Times London. 2011. 50 p.

13. Neema P, Ashish K, Dilys R. Conservation with social justices? The role of community conserved areas in achieving the millennium development goals. 2009.

14. Margaret T, Okorodudu Fubara. Law of environmental protection (materials and text). Ibadan: Caltop Publications Nigeria Limited; 1998.

15. Smith Robert Leo, Smith Thomas M. Ecology and field biology. 6th Ed. An Imprint of Addison Wesley Longman, Inc; 2001.

16. Smith Robert Leo. Elements of ecology. 3rd Ed. Addison-Wesley Educational Publishers, Inc; 1992.

17. Siddiqui NA, Akbar Z. Natural resources and environmental management systems. New Delhi: Khanna Publishers; 2008.

18. Jimoh HI. Man Environment interactions in contemporary Nigeria. In: Jimoh HI, Ifabiyi IP, editors. Contemporary issues in environmental studies. llorin, Nigeria: Haytee Press and Publishing Co. Ltd; 2000.

19. Olorunfemi JF, Jimoh HI. Anthropogenic activities and the environmental studies, Ilorin Nigeria. Haytee Press and Publishing Co. Ltd; 2000.

20. Raheem UA. The physical and cultural environment. In Jimoh HI, Ifabiyi IP, editors. Contemporary issues in Environmental studies, Ilorin Nigeria: Haytee Press and Publishing Co. Ltd; 2000. 
21. Jeje LK, Adesina FA. Man and environment: an introductory note. Edo, Nigeria: Research, evaluation resources and development consultancy; 1996.

22. Allaby M. Macmillian dictionary of the environment. London: Macmillian; 1988.

23. Lexicon encyclopaedia. Academic American encyclopaedia. 1985.

24. Omisore EO. The Physical implications of conservation of historical sites in Ile-Ife. Unpublished PhD Thesis, Ile-Ife. Nigeria: Obafemi Awolowo University; 2002.

25. Chauhan BS. Environmental studies. University Science Press Laxmi Publication Pvt. Ltd; 2011.

26. Cunningham WP, Cunningham MA, Saigo B. Environmental sciences; a global concern. 8th ed. New York: McGraw- Hill Companies inc, 2005.

27. Adegoke A. The challenges of environmental management in Africa: the Nigerian experience. Proceedings of the fifth Annual Convention and Scientific Assembly. 2000;(2):12-23.

28. Mackey BG. Environmental scientists advocacy and the future of earth. Environmental Conservation. 1999;26(4):245-249.

29. Ajibade LT. Techniques of creating environmental awareness in Nigeria. In: Jimoh HI, Ifabiyi IP, editors. Contemporary Issues in Environmental Studies. Ilorin Nigeria. Haytee Press and Publishing Co. Ltd; 2000.
30. Sada PO. Development and the environment: a conceptual framework for environmental management. In: Sada R, Odemerho FO, editors. Environmental issues and management. Evans Brother (Nig. Publisher Ltd). 1988. 27 p.

31. Faniran A, Adeboyejo AF. Environmental education and awareness for effective environmental protection and management in nigeria. Journal of the Nigerian Institute of Town Planners. 1999:1-13.

32. Obateru RI. The structure of physical planning Administration. Department of Town and Regional Planning, the Polytechnic, Ibadan; 1986.

33. Jiriko KG. Effective urban management and government for sustainable cities in Nigeria in the $21^{\text {st }}$ Century. Journal of the Nigeria Institute of Town Planners. 1999;XII:41-56.

34. Federal Republic of Nigeria. Guidelines for local government reform, Kaduna, government printer. 1976.

35. Santra SC. Environmental science. New Delhi: New Central Book Agency (p) Ltd; 2011.

36. Kolk A. Economics of environmental management. England: Pearson Education Limited; 2000. ISBN: 0-273-64238-3.

37. Age AI, Igbashal AA, Shaakaa C. Sustainable agricultural and natural resources development in contemporary Nigeria. Nigeria; Cultural Research Publications Uyo; 2005. 